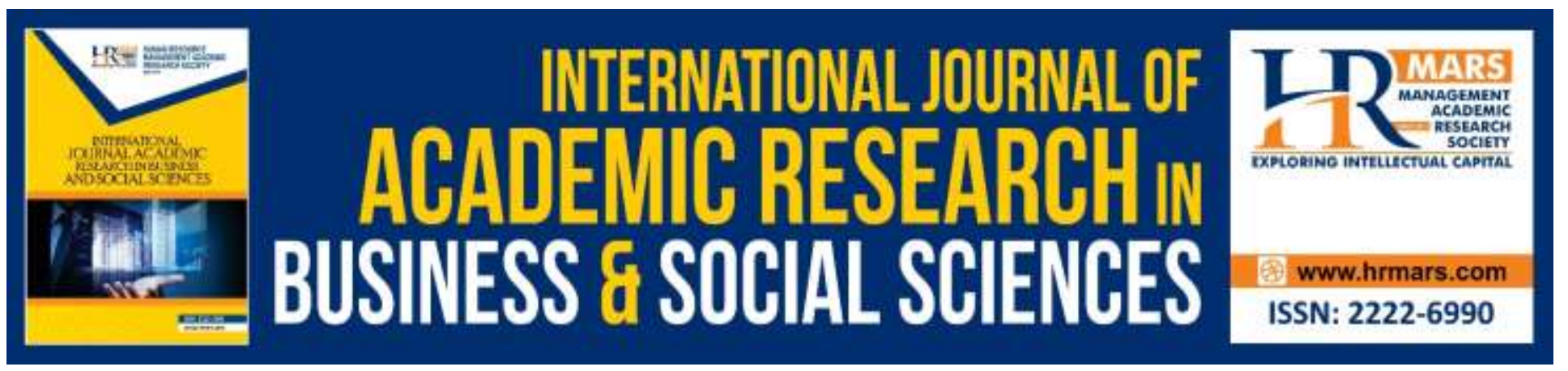

\title{
Constraining Factors of Parents' Maintenance among Working Children in Terengganu, Malaysia
}

Syh Noorul Madihah Syed Husin, Tengku Fatimah Muliana Tengku Muda, Siti Fatimah Salleh, Siti Khatijah Ismail, Sumayyah Abdul Aziz, \& Wan Mohd Yusoff Wan Chik

To Link this Article: http://dx.doi.org/10.6007/IJARBSS/v9-i11/6601 DOI: 10.6007/IJARBSS/v9-i11/6601

Received: 10 October 2019, Revised: 30 October 2019, Accepted: 03 November 2019

Published Online: 13 November 2019

In-Text Citation: (Husin et al, 2019)

To Cite this Article: Husin, S. N. M. S., Muda, T. F. M. T., Salleh, S. F., Ismail, S. K., Aziz, S. A., \& Chik, W. M. Y. W. (2019). Constraining Factors of Parents' Maintenance among Working Children in Terengganu, Malaysia. International Journal of Academic Research in Business and Social Sciences, 9(11), 811-824.

Copyright: (C) 2019 The Author(s)

Published by Human Resource Management Academic Research Society (www.hrmars.com)

This article is published under the Creative Commons Attribution (CC BY 4.0) license. Anyone may reproduce, distribute, translate and create derivative works of this article (for both commercial and non-commercial purposes), subject to full attribution to the original publication and authors. The full terms of this license may be seen at: http://creativecommons.org/licences/by/4.0/legalcode

Vol. 9, No. 11, 2019, Pg. 811 - 824

Full Terms \& Conditions of access and use can be found at http://hrmars.com/index.php/pages/detail/publication-ethics 


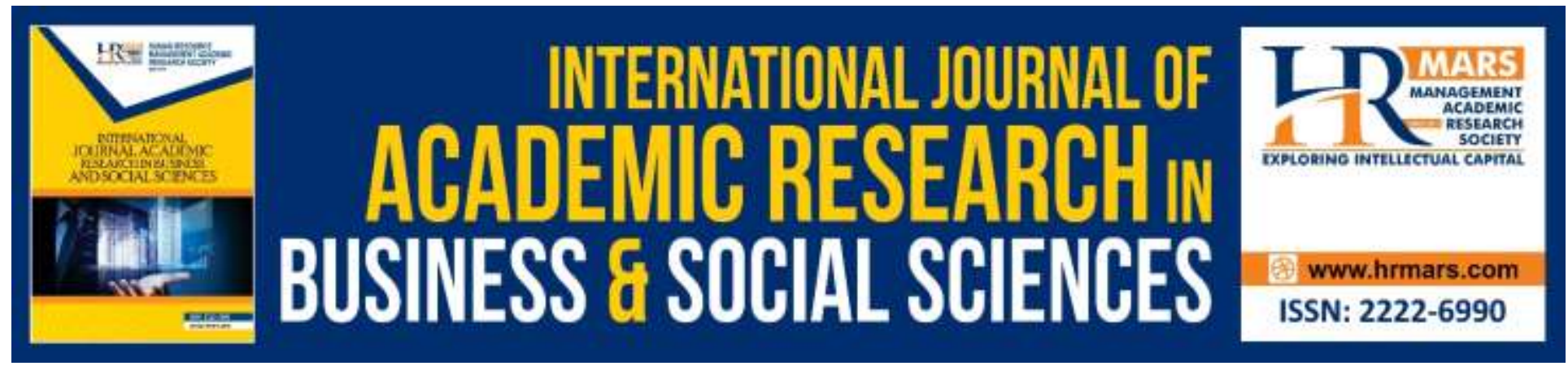

\title{
Constraining Factors of Parents' Maintenance among Working Children in Terengganu, Malaysia
}

\author{
Syh Noorul Madihah Syed Husin, Tengku Fatimah Muliana \\ Tengku Muda, Siti Fatimah Salleh, Siti Khatijah Ismail, Sumayyah \\ Abdul Aziz, \& Wan Mohd Yusoff Wan Chik \\ Department of Syariah, Faculty of Islamic Contemporary Studies, Universiti Sultan Zainal Abidin, \\ Malaysia
}

\begin{abstract}
Parents' maintenance is an obligation due to a child provided that both parties meet certain criteria as outlined by Islam. The injunction is however ignored by some children although the obligation has been agreed by the fuqaha based on the naqli and aqli arguments. Cases of parents who have been neglected by children, especially the aged and incapacitated parents, are often a dominant topic in newspapers. These circumstances illustrate that parental care, which is of the primary obligation of a child, is still at unsatisfactory level especially when it comes to maintenance. Therefore, this study aimed to identify the constraining factors encountered by the working children in fulfilling their responsibility towards parents' maintenance. This is a quantitative research method whereby 291 respondents from the academic staff of three public universities in Terengganu, Malaysia were selected through stratified random sampling method. The study employed questionnaire as the research instrument. The data were then analyzed using the Software Package for Social Sciences (SPSS) version 20.0 with a focus on descriptive statistics to determine the constraining factors among working children to financially support the parents. The study shows that among the dominant constraining factors are time management and location. The results of this study suggested the need to develop a model on parents' maintenance plan. This shall facilitate the working children to overcome the major constraints in providing maintenance to the parents.
\end{abstract}

Keywords: Maintenance, Parents' Financial Support, Constraining Factors of Parents' Financial Support.

\section{Introduction}

Parents' maintenance is obligated upon Muslims progeny once they fulfilled the conditions outlined (Al-Kasani, 2000; Al-Dardir; Al-Shirazi, 1995; Ibn-Qudamah, 1997; Jusoh, Salleh, Embong, 
\& Mamat, 2018). The obligation which is established on the sources of the naqli (Al-Sartawi, 1997) and the aqli (Zaidan, 2000) is to ensure that parents' sustenance, clothing and shelter are well maintained should they no longer able to manage on their own, especially in the case of the elderly parents. Through fulfilling the obligation of supporting the parents, not only that parents' welfare is taken care of, rather the children shall have the opportunity to serve their parents as prescribed in the Qur'an and the hadith.

Although the injunction for parents' maintenance has been written in the major Islamic sources and justified by scholars (Al-Sartawi, 1997), in reality, cases of neglected parents among society are continuing. Observing the current scenario, the issue of neglected parents, especially among the elderly, is considered as an isolated issue (Bidin, 2013), rather hidden from public knowledge and marginalized (Abdul-Aziz, 2001). As a result of the frequent negligence, children and society took no notice on the implementation of parents' financial support. Maintenance requirements for parents including food are ignored by those of children with fulfilling criteria. According to Sharif et. al (2015), there are many children who did not provide their parents with money for living or to buy their necessities. Parents are depending only on the money provided by the Social Welfare Department (JKM). In the context of social science, neglect of such support is included in financial and material aspects. Alavi (2011) cited that negligence in financial and material aspects are included in the failure of guardian in providing basic care or necessities such as safety, emotional and physical treatment. Such abandonment can lead to many consequences for parents in physical, emotional and so on. Some parents who deal with this situation have to expect and seek monthly help from family members to survive their daily lives (Tan \& $\mathrm{Ng}, 2000$ ). According to Husin et. al. (2019), the occurrence of such cases is deplorable, since Islam described children who are financially stable and capable to hold the responsibility to provide their parents' maintenance, without having to be informed or requested by the parents. Unfortunately, a study by Salleh and Husin (2014); Peprah (2018) found that the implementation of maintenance and financial support are also flawed for parents with disabilities. The results of their study found that some of the respondents had inconsistent support for their visually impaired parents. Even some of the respondents failed to comprehend such responsibility as children. This is regrettable for parents, and even distressing that they feel abandoned and neglected without being given the proper rights by the children.

Above presentation illustrates that the issue of parents' maintenance as an obligation for the children needs to be familiarized into society to reduce cases of neglected parents, especially in matters of maintenance. The causes and factors need to be examined to find the best solution for both parents and children. From the children's perspective, it is likely that many of them are aware of and understand the concept of financing their parents' living expenses. However, the surrounding environment and condition have caused them to face various obstacles in exercising the obligation. The current condition of employment has led many children to reside far from their parents to earn their living. Therefore, this article is written to explore the constraining factors in parents' maintenance to ensure that it is precisely identified to enable further research in appropriating the best solution. 
INTERNATIONAL JOURNAL OF ACADEMIC RESEARCH IN BUSINESS AND SOCIAL SCIENCES

Vol. 9, No. 11, November, 2019, E-ISSN: 2222-6990 @ 2019 HRMARS

\section{Methodology}

In order to achieve the above-mentioned objective, the following are the research design, instrumentation, and data analysis used in this study:

\section{Study Location, Population and Sample}

This is a survey study that involved quantitative data collection using a questionnaire as the research instrument. According to Piaw (2006), the survey is a study on census selection of subjects from the population as respondents, collecting information from respondents, and then analyzing that information to answer the research questions. The population study consisted of full-time academic staff from three public universities in the state of Terengganu, Malaysia which are Universiti Sultan Zainal Abidin (UniSZA), Universiti Malaysia Terengganu (UMT) and Universiti Teknologi Mara (UiTM). The sample selection criteria of the academic staff in each university are based on their position as educated professionals, and fulfill the obligatory conditions in parents' maintenance, with an income of moderate and above. The total population is 1282 people. In detail, the number consists of 401 people from Universiti Sultan Zainal Abidin representing Gong Badak, Medicine and Besut campuses (https://edata.unisza.edu.my, 2018), 493 people from Universiti Malaysia Terengganu (Records Division Officer of University Malaysia Terengganu, personal communication, August 5, 2018) and 388 people from Universiti Teknologi Mara, Terengganu consisted of Dungun, Kuala Terengganu and Bukit Besi campuses (Records Division Officer of University Technology Mara, Dungun Campus, personal communication, August 5, 2018). From the total population, 291 samples were taken using the stratified random sampling according to the percentage of population for each university. The number of these samples is based on the sampling table previously presented by Krejcie and Morgan (1970). The following is a sampling selection table based on the population ratio of each university:

\begin{tabular}{|l|l|l|}
\hline \multicolumn{3}{|l|}{ Table 1: Total Number of Populations and Respondents } \\
\hline University & $\begin{array}{l}\text { Number of } \\
\text { Populations }\end{array}$ & $\begin{array}{l}\text { Number of } \\
\text { Samples }\end{array}$ \\
\hline $\begin{array}{l}\text { Universiti Sultan Zainal } \\
\text { Abidin }\end{array}$ & 401 & 91 \\
\hline $\begin{array}{l}\text { Universiti Malaysia } \\
\text { Terengganu }\end{array}$ & 493 & 112 \\
\hline Universiti Teknologi Mara & 388 & 88 \\
\hline Total of Samples: & 291 \\
\hline
\end{tabular}

Source: Student Affairs Department of each public universities

\section{Research Instrument}

The questionnaire was used as a research instrument in the process of data collection. The questionnaire was constructed and collected from July 31 to September 19, 2018, with the help 
of the Google Forms software developed by Google LLC on October 31, 2012 (Google LLC, n.d). The questionnaire was prepared in the Malay language in accordance with the main and daily language of the respondents. The questionnaire is divided into two sections. Each respondent was required to provide information about their demographics in section $A$, while in section $B$, the questions about the constraining factors in parents' maintenance are involved. The questions in section B include 5 factors which are financial factors, time constraints, home location, lack of awareness of the obliged maintenance and negligence. The entire contents of the questionnaire can be summarized as in the following table:

\begin{tabular}{|c|c|c|c|}
\hline Section & \multicolumn{2}{|l|}{ Description } & Variable \\
\hline \multirow{10}{*}{ A } & \multirow{10}{*}{\multicolumn{2}{|c|}{$\begin{array}{l}\text { Respondents' Demographic } \\
\text { Data }\end{array}$}} & Gender \\
\hline & & & Age \\
\hline & & & Marital status \\
\hline & & & Monthly Income \\
\hline & & & Estimated Monthly Expenditure \\
\hline & & & Highest Education Level \\
\hline & & & Spouse's Occupation \\
\hline & & & Status of Mother or Father \\
\hline & & & Father's Occupation \\
\hline & & & Mother's Occupation \\
\hline \multirow{12}{*}{ B } & \multirow{12}{*}{$\begin{array}{l}\text { Constraining } \\
\text { Factors in } \\
\text { Parents' } \\
\text { Maintenance }\end{array}$} & \multirow{3}{*}{$\begin{array}{l}\text { Financial } \\
\text { Factor }\end{array}$} & Debt burdens \\
\hline & & & Cost of households \\
\hline & & & Weaknesses in financial management \\
\hline & & \multirow{2}{*}{$\begin{array}{l}\text { Time } \\
\text { Constraint }\end{array}$} & Time constraint to buy necessities \\
\hline & & & Time constraint to manage healthcare \\
\hline & & \multirow{3}{*}{$\begin{array}{l}\text { Home } \\
\text { Location }\end{array}$} & $\begin{array}{l}\text { Staying separately causing the medical care } \\
\text { negligence }\end{array}$ \\
\hline & & & $\begin{array}{l}\text { The home location is the reason for poor } \\
\text { maintenance in terms of basic necessities }\end{array}$ \\
\hline & & & $\begin{array}{l}\text { The home location is the reason for poor financial } \\
\text { maintenance }\end{array}$ \\
\hline & & \multirow{4}{*}{$\begin{array}{l}\text { Lack of } \\
\text { Awareness } \\
\text { of the } \\
\text { Obliged } \\
\text { Maintenance }\end{array}$} & $\begin{array}{l}\text { Awareness of the obligations in parents' } \\
\text { maintenance particularly for their residence }\end{array}$ \\
\hline & & & $\begin{array}{l}\text { Awareness of the obligations of parents' } \\
\text { maintenance }\end{array}$ \\
\hline & & & $\begin{array}{l}\text { Awareness of the obligations of parents' medical } \\
\text { care }\end{array}$ \\
\hline & & & $\begin{array}{l}\text { Awareness of the child's responsibilities to support } \\
\text { the parents }\end{array}$ \\
\hline
\end{tabular}




\begin{tabular}{|l|l|l|}
\hline \multirow{2}{*}{$\begin{array}{l}\text { Negligence } \\
\text { Factor }\end{array}$} & $\begin{array}{l}\text { Rarely visiting the parents caused the negligence of } \\
\text { providing money }\end{array}$ \\
\cline { 3 - 3 } & $\begin{array}{l}\text { Excessive working commitments caused the } \\
\text { negligence of providing money }\end{array}$ \\
\cline { 3 - 3 } & $\begin{array}{l}\text { Excessive working commitments caused the } \\
\text { negligence in providing basic necessities }\end{array}$ \\
\hline
\end{tabular}

Source: Research findings

\section{Data Analysis}

The data analyzed in this study were descriptive statistics. For respondents' demographic data, the analysis focused only on frequency and percentage distributions. Whereas for the data of constraining factors in parents' maintenance, in addition to frequency and percentage distributions, the mean and standard deviation analysis were also extracted to obtain a clearer picture of the constraining factors in parents' maintenance.

\section{Findings and Discussions}

\section{Demographic Respondents}

The total number of respondents is 291 academic staff from UniSZA, UMT and UiTM. The population consisted of 89 males (30.6\%) and 202 females (69.4\%) mostly are 30 to 39 years old (49.1\%). In terms of monthly income and estimated monthly expenditure, respondents earning RM 8,000 and above are the majority with 116 people representing 39.9\%, followed by those earning RM 7,000 to RM 7,999 with 52 people (17.9\%). Meanwhile, the lowest monthly income group which is between RM 3,000 to RM 3,999 are only 21 people (7.2\%). This finding is consistent with the career of the respondents as lecturers in a public university serving under the University Lecturer Services Scheme and at least obtained income with DS 45 grade (Awam, 2019). Respondents' estimated monthly expenditure also show the same pattern as the monthly income data, which is in direct proportion. The frequency of group with highest estimated monthly expenditure are those spending over RM 5,000 and above which is 98 people (33.7\%), followed by the group spending between RM 4,000 and RM 4,999 which is 70 people (24.1\%). Only 8 respondents $(2.7 \%)$ spent the lowest estimated monthly expenditure which is RM 1,900 and below.

From the total population, 155 people (53.3\%) graduated with a Doctor of Philosophy. The remaining consisted of those with a Master's degree (39.9\%) and a Bachelor's Degree (6.9\%). A total of 256 respondents (88\%) are married and out of these respondents, $85.2 \%$ of their spouses had their jobs and income. This suggests that the household income of the respondents is also influenced by the income of the spouse. Respondents of this study also comprised 146 people (50.2\%) who had both of their parents, 109 people (37.5\%) had only one of them and 36 people $(12.4 \%)$ had no parents. For the respondents who still have a parent, the majority of the respondents' fathers are retirees (38.1\%), while the majority of the mothers $(56.0 \%)$ are unemployed. All of these respondents' demographic data can be found in table 3 below: 


\begin{tabular}{|l|l|l|}
\hline \multicolumn{3}{|l|}{ Table 3: Demographic Profile of Respondents } \\
\hline GENDER & Frequency & Percentage (\%) \\
\hline Male & 89 & 30.6 \\
\hline Female & 202 & 69.4 \\
\hline TOTAL & 291 & 100.0 \\
\hline AGE & Frequency & Percentage (\%) \\
\hline 29 and below & 3 & 1.0 \\
\hline 30 to 39 years & 143 & 49.1 \\
\hline 40 to 49 years & 107 & 36.8 \\
\hline 50 and above & 38 & 13.1 \\
\hline TOTAL & 291 & 100.0 \\
\hline MARITAL STATUS & Frequency & Percentage (\%) \\
\hline Single & 28 & 9.6 \\
\hline Married & 256 & 88.0 \\
\hline Widowed & 7 & 2.4 \\
\hline TOTAL & 291 & 100.0 \\
\hline MONTHLY INCOME & Frequency & Percentage (\%) \\
\hline RM 3,000 - RM 3,999 & 21 & 7.2 \\
\hline RM 4,000 - RM 4,999 & 25 & 8.6 \\
\hline RM 5,000 - RM 5,999 & 36 & 12.4 \\
\hline RM 6,000 - RM 6,999 & 41 & 14.1 \\
\hline RM 7,000 - RM 7,999 & 52 & 17.9 \\
\hline RM 8,000 and above & 116 & 39.9 \\
\hline TOTAL & 291 & 100.0 \\
\hline MONTHLY EXPENSES & Frequency & Percentage (\%) \\
\hline RM 1,900 and below & 8 & 2.7 \\
\hline RM 2,000 - RM 2,999 & 47 & 16.2 \\
\hline RM 3,000 - RM 3,999 & 68 & 23.4 \\
\hline RM 4,000 - RM 4,999 & 70 & 24.1 \\
\hline RM 5,000 and above & 98 & 33.7 \\
\hline TOTAL & 291 & 100.0 \\
\hline HIGHEST EDUCATION LEVEL & Frequency & Percentage (\%) \\
\hline Bachelor & 20 & 6.9 \\
\hline Masters & 116 & 39.9 \\
\hline PhD & 155 & 53.3 \\
\hline TOTAL & 291 & 100.0 \\
\hline MARITAL STATUS & Frequency & Percentage (\%) \\
\hline Single & 28 & 9.6 \\
\hline & & \\
\hline
\end{tabular}


INTERNATIONAL JOURNAL OF ACADEMIC RESEARCH IN BUSINESS AND SOCIAL SCIENCES Vol. 9, No. 11, November, 2019, E-ISSN: 2222-6990 @ 2019 HRMARS

\begin{tabular}{|l|l|l|}
\hline Married & 256 & 88.0 \\
\hline Widowed & 7 & 2.4 \\
\hline TOTAL & 291 & 100.0 \\
\hline $\begin{array}{l}\text { SPOUSE'S EMPLOYMENT STATUS (IF } \\
\text { MARRIED) }\end{array}$ & Frequency & Percentage (\%) \\
\hline Yes & 218 & \\
\hline No & 38 & 85.2 \\
\hline TOTAL & 256 & 14.8 \\
\hline PARENTS & Frequency & 100.0 \\
\hline Only one is alive & 109 & Percentage (\%) \\
\hline Both are alive & 146 & 37.5 \\
\hline Both have passed away & 36 & 50.2 \\
\hline TOTAL & 291 & 12.4 \\
\hline FATHER'S EMPLOYMENT STATUS & Frequency & 100.0 \\
\hline Working & 35 & Percentage (\%) \\
\hline Retired & 111 & 12.0 \\
\hline Not working & 46 & 38.1 \\
\hline Not relevant & 99 & 15.8 \\
\hline TOTAL & 256 & 34.0 \\
\hline MOTHER'S EMPLOYMENT STATUS & Frequency & 100.0 \\
\hline Working & 18 & Percentage (\%) \\
\hline Retired & 62 & 6.2 \\
\hline Not working & 163 & 21.3 \\
\hline Not relevant & 48 & 56.0 \\
\hline TOTAL & 256 & 16.5 \\
\hline Source: Research findings & 100.0 \\
\hline
\end{tabular}

Source: Research findings

\section{Constraining Factors in Parents' Maintenance}

In order to determine the constraining factors in parents', this study presents several questionnaire items that represent five factors; i) financial factor, ii) time constraints, iii) home location, iv) lack of awareness of the obliged maintenance and v) negligence. The following is a detailed study of each constraint:

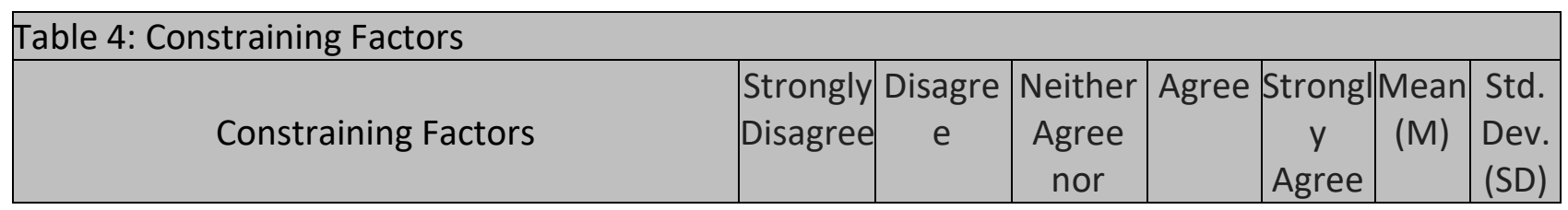


INTERNATIONAL JOURNAL OF ACADEMIC RESEARCH IN BUSINESS AND SOCIAL SCIENCES

Vol. 9, No. 11, November, 2019, E-ISSN: 2222-6990 @ 2019 HRMARS

\begin{tabular}{|c|c|c|c|c|c|c|c|c|}
\hline & & & & Disagree & & & & \\
\hline \multirow{3}{*}{$\begin{array}{l}\text { Financial } \\
\text { Factor }\end{array}$} & Debt burdens (C18) & $\begin{array}{c}191 \\
(65.6 \%)\end{array}$ & $\begin{array}{c}54 \\
(18.6 \%) \\
\end{array}$ & $\begin{array}{c}15 \\
(5.5 \%) \\
\end{array}$ & $\begin{array}{c}25 \\
(8.6 \%)\end{array}$ & $\begin{array}{c}5 \\
(1.7 \%)\end{array}$ & 1.62 & 1.035 \\
\hline & Cost of households (C 20) & $\begin{array}{c}200 \\
(68.7 \%) \\
\end{array}$ & $\begin{array}{c}60 \\
(20.6 \%) \\
\end{array}$ & $\begin{array}{c}15 \\
(5.2 \%) \\
\end{array}$ & $\begin{array}{c}13 \\
(4.5 \%) \\
\end{array}$ & $\begin{array}{c}3 \\
(1.0 \%) \\
\end{array}$ & 1.48 & 0.864 \\
\hline & $\begin{array}{l}\text { Weaknesses in financial } \\
\text { management (C 25) }\end{array}$ & $\begin{array}{c}205 \\
(70.4 \%) \\
\end{array}$ & $\begin{array}{c}109 \\
(20.3 \%) \\
\end{array}$ & $\begin{array}{c}17 \\
(5.8 \%) \\
\end{array}$ & $\begin{array}{c}9 \\
(3.1 \%) \\
\end{array}$ & $\begin{array}{c}1 \\
(0.3 \%) \\
\end{array}$ & 1.43 & 0.768 \\
\hline \multirow{2}{*}{$\begin{array}{l}\text { Time } \\
\text { Constrai } \\
\text { nt }\end{array}$} & $\begin{array}{l}\text { Time constraint to buy } \\
\text { necessities ( } C 23 \text { ) }\end{array}$ & $\begin{array}{c}71 \\
(24.4 \%)\end{array}$ & $\begin{array}{c}63 \\
(21.6 \%)\end{array}$ & $\begin{array}{c}47 \\
(16.2 \%)\end{array}$ & $\begin{array}{c}72 \\
(24.7 \% \\
)\end{array}$ & $\begin{array}{c}38 \\
(13.1 \% \\
1\end{array}$ & 2.80 & 1.389 \\
\hline & $\begin{array}{l}\text { Time constraint to manage } \\
\text { healthcare (C 29) }\end{array}$ & $\begin{array}{c}141 \\
(48.5 \%)\end{array}$ & $\begin{array}{c}65 \\
(22.3 \%)\end{array}$ & $\begin{array}{c}34 \\
(11.7 \%)\end{array}$ & $\begin{array}{c}46 \\
(15.8 \% \\
)\end{array}$ & $\begin{array}{c}5 \\
(1.7 \%)\end{array}$ & 2.00 & 1.180 \\
\hline \multirow{3}{*}{$\begin{array}{l}\text { Home } \\
\text { Location }\end{array}$} & $\begin{array}{l}\text { Staying separately causing the } \\
\text { medical care negligence ( } C 15)\end{array}$ & $\begin{array}{c}160 \\
(55.0 \%)\end{array}$ & $\begin{array}{c}66 \\
(22.7 \%)\end{array}$ & $\begin{array}{c}21 \\
(7.2 \%)\end{array}$ & $\begin{array}{c}37 \\
(12.7 \% \\
) \\
\end{array}$ & $\begin{array}{c}7 \\
(2.4 \%)\end{array}$ & 1.85 & 1.153 \\
\hline & $\begin{array}{l}\text { The home location is the reason } \\
\text { for poor maintenance in terms of } \\
\text { basic necessities (C 17) }\end{array}$ & $\begin{array}{c}148 \\
(50.9 \%)\end{array}$ & $\begin{array}{c}46 \\
(15.8 \%)\end{array}$ & $\begin{array}{c}14 \\
(4.8 \%)\end{array}$ & $\begin{array}{c}70 \\
(24.1 \% \\
1\end{array}$ & $\begin{array}{c}13 \\
(4.5 \%)\end{array}$ & 2.15 & 1.380 \\
\hline & $\begin{array}{l}\text { The home location is the reason } \\
\text { for poor financial maintenance } \\
\text { (C 27) }\end{array}$ & $\begin{array}{c}217 \\
(74.6 \%)\end{array}$ & $\begin{array}{c}55 \\
(18.9 \%)\end{array}$ & $\begin{array}{c}16 \\
(5.5 \%)\end{array}$ & $\begin{array}{c}2 \\
(0.7 \%)\end{array}$ & $\begin{array}{c}1 \\
(0.3 \%)\end{array}$ & 1.33 & 0.645 \\
\hline \multirow{4}{*}{$\begin{array}{l}\text { Lack of } \\
\text { Awarene } \\
\text { ss of the } \\
\text { Obliged } \\
\text { Mainten } \\
\text { ance }\end{array}$} & $\begin{array}{l}\text { Awareness of the obligations in } \\
\text { parents' maintenance } \\
\text { particularly for their residence (C } \\
\text { 19) }\end{array}$ & $\begin{array}{c}190 \\
(65.3 \%)\end{array}$ & $\begin{array}{c}51 \\
(17.5 \%)\end{array}$ & $\begin{array}{c}23 \\
(7.9 \%)\end{array}$ & $\begin{array}{c}13 \\
(4.5 \%)\end{array}$ & $\begin{array}{c}14 \\
(4.8 \%)\end{array}$ & 1.66 & 1.110 \\
\hline & $\begin{array}{l}\text { Awareness of the obligations of } \\
\text { parents' maintenance (C 21) }\end{array}$ & $\begin{array}{c}140 \\
(48.1 \%)\end{array}$ & $\begin{array}{c}71 \\
(24.4 \%)\end{array}$ & $\begin{array}{c}36 \\
(12.4 \%)\end{array}$ & $\begin{array}{c}11 \\
(3.8 \%)\end{array}$ & $\begin{array}{c}33 \\
(11.3 \% \\
1\end{array}$ & 2.06 & 1.334 \\
\hline & $\begin{array}{l}\text { Awareness of the obligations of } \\
\text { parents' medical care (C 22) }\end{array}$ & $\begin{array}{c}84 \\
(28.9 \%)\end{array}$ & $\begin{array}{c}103 \\
(35.4 \%)\end{array}$ & $\begin{array}{c}69 \\
(23.7 \%)\end{array}$ & $\begin{array}{c}21 \\
(7.2 \%)\end{array}$ & $\begin{array}{c}14 \\
(4.8 \%)\end{array}$ & 2.23 & 1.088 \\
\hline & $\begin{array}{l}\text { Awareness of the child's } \\
\text { responsibilities to support the } \\
\text { parents (C 24) }\end{array}$ & $\begin{array}{c}218 \\
(74.9 \%)\end{array}$ & $\begin{array}{c}53 \\
(18.2 \%)\end{array}$ & $\begin{array}{c}17 \\
(5.8 \%)\end{array}$ & $\begin{array}{c}1 \\
(0.3 \%)\end{array}$ & $\begin{array}{c}2 \\
(0.7 \%)\end{array}$ & 1.34 & 0.667 \\
\hline \multirow{2}{*}{$\begin{array}{l}\text { Negligen } \\
\text { ce Factor }\end{array}$} & $\begin{array}{l}\text { Rarely visiting the parents caused } \\
\text { the negligence of providing } \\
\text { money (C 16) }\end{array}$ & $\begin{array}{c}247 \\
(84.9 \%)\end{array}$ & $\begin{array}{c}35 \\
(12.0 \%)\end{array}$ & $\begin{array}{c}3 \\
(1.0 \%)\end{array}$ & $\begin{array}{c}5 \\
(1.7 \%)\end{array}$ & $\begin{array}{c}1 \\
(0.3 \%)\end{array}$ & 1.21 & 0.574 \\
\hline & $\begin{array}{l}\text { Rarely visiting the parents } \\
\text { caused the negligence of } \\
\text { providing money (C 26) }\end{array}$ & $\begin{array}{c}220 \\
(75.6 \%)\end{array}$ & $\begin{array}{c}55 \\
(18.9 \%)\end{array}$ & $\begin{array}{c}12 \\
(4.1 \%)\end{array}$ & $\begin{array}{c}3 \\
(1.0 \%)\end{array}$ & $\begin{array}{c}1 \\
(0.3 \%)\end{array}$ & 1.32 & 0.635 \\
\hline
\end{tabular}


INTERNATIONAL JOURNAL OF ACADEMIC RESEARCH IN BUSINESS AND SOCIAL SCIENCES

Vol. 9, No. 11, November, 2019, E-ISSN: 2222-6990 @ 2019 HRMARS

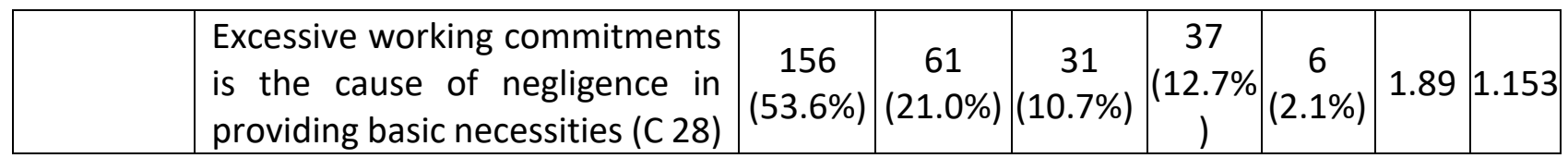

Source: Research findings

Table 4 above shows respondents' response distribution on the constraining factors in parents' maintenance by percentage and mean together with the standard deviation for each item. Overall, the mean ranged from only 1.21 to 2.80 and did not reach 3 . This indicates that although each of the tested factors had little impact on the respondents' maintenance to parents, it did not show a significant effect. The mean value is 2.80 (SD =1.389) in item C 23 related to the time constraint factor, with the study showing $37.8 \%$ of respondents admitted that time constraint is a constraining factor in parents' maintenance for needs and necessities. This percentage is higher compared to the other factors which are only $28.6 \%$ and below. The lowest mean is on item C 16 which is the factor of negligence with 1.21 (SD = 0.574). Findings for this item indicate that only $2.0 \%$ of respondents stated that infrequent visitation of the parents is a constraining factor in parents' maintenance.

From table 4 above, it can be observed that among the 5 constraining factors studied, the most significant factor is the time constraint. This is evident when the mean for both items testing the factor is 2.00 (C 29) and 2.80 (C 23), compared to the mean for the other items showing more than $1 / 3$ of the total item is 1.50 and below. This situation reflects the time constraints faced by the respondents as one of the reasons for the occurrence of neglected parents or insufficiency in parents' financial support. Besides, home location factor is also considered as a constraining factor in parents' maintenance by most respondents. From 3 items that tested for this factor, it was found that two of them had been agreed by at least $15 \%$ of the total respondents. For item C 17 that stated residence as the cause of poor maintenance to parents, $28.6 \%$ of respondents agreed with the statement with a mean of 2.15 (SD = 1.380). The mean of item $C 15$ which identified residence as a cause of poor maintenance of parents's medical care is 1.85 (SD =1.153), indicating that $15.1 \%$ of respondents agreed with the statement. The findings for these two items were slightly different from item C 27 which stated home location as a cause of poor provision of parents' maintenance, as the mean is only $1.33(\mathrm{SD}=0.645)$.

From the results, it was found that among the factors with a low level of acceptance are the financial and negligence factors. Financial factor is tested with 3 items, which each mean score is lower than 2. The highest mean of the 3 items is item C 18 with $1.62(S D=1.035)$, indicating that debt burden as the constraining factor in parents' maintenance. The negligence factor is tested with 3 items is also recorded the mean score below 2. Even one of these items (C16) had the lowest mean score among all items which is 1.21 (SD = 0.574). This finding illustrates that financial and negligence factors are not significant factors in the constraints for parents' maintenance. 


\section{Discussion}

Based on the observation of the research findings, it is generally shown that all factors influence the parents' maintenance from the respondents. Among the 5 factors studied, many respondents stated that time constraint and home location are the constraining factors in parents' maintenance. This is evident when the mean for each related item is relatively high compared to the mean for the other items. . In fact, the issue of the time constraint is not only a hindrance to the parents' financial support, but past studies show that failure in time management can affect many other issues related to social life. In the field of work, for example, time constraints have affected the level of work pressure of a teacher (Royo \& Woo, 2010; Mohamad, 2015). Meanwhile, in the issue of child education, the studies of Lareau (2000), Harris and Goodall (2008) and Moon and Ivins (2004) have found that time constraint is a major obstacle to parents when it comes to parental care, education and learning. This shows that the research findings are approved and supported by past studies which concluded time constraint as a dominant factor that may influence human behavior in daily life. In the case of parents' maintenance, it is viewed as a major factor in the failure of children's management in parents' maintenance.

The findings related to time constraint as a constraining factor in parents' maintenance also specifically reinforce past studies related to care and abandonment of the parents. A study conducted by Nayan (2006) on the decreasing concern of community towards parents, especially those of the elderly, found that among the main factors contributing to the negligence attitude was the children's extremely active engagement to their career in pursuit of luxury which causing them to prioritize career over parents. This suggests that children are spending lesser time paying attention to parents due to their working commitments. Azman and Mahmud (2017) in their study found that highly educated and greater working position for children nowadays are increasingly causing them to hustle and abandoned their parents. According to researchers, excessive involvement and commitment in careers, especially for women, has led them to spend less time attending their parents, until some admit that they missed the opportunity to manage medical care and parents' needs and necessities.

The home location factor is also more likely to be selected by respondents as a constraining factor in parents' maintenance. From the 3 items tested, 2 of them indicated that more than $15 \%$ of respondents acknowledge home location as a hindrance for them to give maintenance particularly in medical care and parents' needs and necessities with the mean of 1.85 and 2.15. For another item with a relatively low mean of 1.33 , this slight difference was associated with financial support. This low mean suggested that home location is less significance to the problem of parents' maintenance. This is probably because the money can be transferred online to the parents' account etc. In reality, when children stay close to their parents or particularly staying with them, the implementation of the parents' maintenance by the children becomes easier. According to Glaser (1997), children living with parents can provide better assistance including a variety of daily and financial activities than children living apart. Therefore, it is not surprising that some respondents consider the reason for their place of residence as a constraining factor in parents' maintenance. The findings of this study approved the findings for 
a study related to the social relationship between children and parents. In that research, Ahmad and Ismail (2011) found that the main factor that created differences in the frequency for a social relationship such as visiting the parents was due to the distance of children's home locations to their parents' homes. Children who stay closer often come to visit their parents, as opposed to children who stay far to visit once a while.

Subsequent findings suggested that financial and negligence factors are the minor constraining factors in parents' maintenance. For items that tested financial factor, the mean was relatively low at only 1.43 to 1.62 . As well as items related to negligence factor which are lower than 2. It can be concluded that many of the respondents were able to manage their income distribution and did not make financial problems a cause to neglect their parents' rights. This finding indirectly supports the findings of a study conducted by Nassuruddin and Azahari (2017) who found that among the three key factors to the existence of parents' maintenance by the children is an economic factor. In the case of negligence, the finding illustrates that negligence is not the constraining factor in parents' maintenance. In fact, this finding indirectly indicates that respondents as children did not deliberately avoid to fulfill their obligations in parents' maintenance.

\section{Conclusion}

In conclusion, the constraints faced by the working children in terms of parents' maintenance can be overcome provided that the children are aware of their obligation. Through this study, financial issues and negligence are not the main constraints for respondents. Relatively, this shows that the working children are capable of providing maintenance to the parents. However, in order for them to effectively exercise the obligation, it shall require consistent effort, support and continuous observation by themselves or by the second party. This is because one of the main constraining factors recognized by the respondents is time and home location. These constraints are only the external factors that may be resolved by a systematic and structured approach. Therefore, in order to improve the quality of parents' maintenance and to overcome the constraints faced by the working children, an aspect that should be emphasized is the approach or method of an effective implementation. The implications of this study proposes that a model of parents' maintenance plan to be developed to facilitate the working children to overcome the major constraints in the financing process.

\section{Acknowledgement}

This article is part of a research fund entitled "Kekangan Pembiayaan Nafkah Ibu Bapa Dan Penyelesaiannya Melalui Model Pelan Pembiayaan Nafkah Ibu Bapa Patuh Syariah" sponsored and managed by the Center for Research Excellence \& Incubation Management (CREIM), Sultan Zainal Abidin University (UniSZA), Gong Badak Campus, 21300 Kuala Nerus, Terengganu, Malaysia. 


\section{Corresponding Author}

Syh Noorul Madihah Syed Husin (Ph.D), Department of Syariah, Faculty of Islamic Contemporary Studies, Universiti Sultan Zainal Abidin (UniSZA), Kampus Gong Badak, 21300 Kuala Nerus. Terengganu, Malaysia.

Email: madihah@unisza.edu.my

\section{References}

Ahmad, W. I., \& Ismail, Z. (2011). Hubungan sosial warga tua dengan anak dewasa: Kes masyarakat desa Kelantan. Jurnal Pembangunan Sosial, 14, 19-42.

Alavi, K., Sail, R. M., Idris, K., Samah, A. A., \& Chan, C. (2011). Emotional support needs in caring for the elderly parents by the adult children. E-Bangi: Journal of Social Sciences and Humanities. 6(1), 102-114.

Al-Dardir, A. A. A. I. M. I. A. (d.u). Al-sharh al-saghir ala aqrab al-masalik ila mazhab al-Imam Malik. Vol. 3. N.p: Matba'ah Isa al-Babi al-Halabi wa Shurakahu.

Al-Kasani, A. A. A. B. I. M. (2000). Bada'i' al-sana'i'fi tartib al-shara'i'. (ed). Darwish, M. A. I. Y. Vol. 3. Beirut: Dar Ihya' al-Turath al-Arabi.

Al-Sartawi, M. A. (1997). Syarah qanun al-ahwal al-syakhsiyyah. Jordan: Dar al-Fikr.

Al-Shirazi, A. I. I. I. A. (1995). Al-muhazzab fi fiqh al-imam al-Shafi'i. (ed). Amirat, Z. Vol. 2. Beirut: Dar al-Kutub al-Ilmiyyah.

Aziz, A. R. (2001). Perubahan populasi warga tua, perkhidmatan penjagaan dan implikasi dasar, in Jemain, A. A., Mohamad, L. Z. \& Mohamed, W. N. (ed). Jaminan sosial warga tua. Selangor: Prentice Hall.

Azman, N. F., \& Mahmud, Z. (2017). Pengalaman mengendali pusat penjagaan warga tua. Proceedings of Seminar on Transdisiplin Education (STEd2017), January 16-17 in Sarawak.

Bidin, A. \& Zabdi, J. (2015). Experience of domestic abuse among Malaysian elderly. Pertanika Journal Social Sciences and Humanities, 23(S).Nov, 107-118.

Glaser, K. (1997). The living arrangements of elderly people. Reviews in Critical Gerontology, 7(01), 63-72.

Google, L. L. C. (2012). Google form. Retrieved 16 October 2018, from web https://docs.google.com > forms.

Harris, A., \& Goodall, J. (2008). Do parents know they matter? Engaging all parents in learning. Educational Research, 50(3), 277-289.

Husin, S. N. M., Muda, T. F. M., Aziz, A. S., Salleh, S. F., Ismail, S. K. \& Chik, W. M. Y. (2019). The types and factors of subsistence-giving from the perspective of shariah. International Journal of Academic Research in Business dan Social Sciences, 9(4), 89-103.

Ibn Qudamah (1997). Al-mughni. (ed). Al-Turki, A. A. I. A. A. \& Al-Halw, A. M. Vol. 11. Riyad: Dar Alam al-Kutub.

Jusoh, A., Salleh, M., Embong, R., \& Mamat, M. (2018). The Influence of Mathematical Teacher Competency on Creative Teaching Practice. International Journal of Academic Research in Progressive Education and Development, 7(4), 397-409. 
Krejcie, R. V., \& Morgan, D. W. (1970). Determining sample size for research activities. Educational and Psychological Measurement, 30, 607-610.

Lareau, A. (2000). Home advantage: Social class and parental intervention in elementary education. Lanham, MD: Roman and Littlefield.

Mohamad, N. (2015). Tekanan kerja dalam kalangan guru: Kajian di sebuah sekolah menengah daerah Kluang Johor Darul Takzim. Academic paper for master, Universiti Utara Malaysia. Unpublished article.

Moon, N., \& Ivins, C. (2004). Parental involvement in children's education. United Kingdom: Department for Education and Skills.

Nassuruddin, A. S. M., \& Azahari R. (2017). Pembiayaan nafkah ibu bapa: Kajian pelaksanaan di Pasir Mas Kelantan. Proceedings of International Conference on Islam, Development and Social Harmony in Southeast Asia 2017, April 11-12 in Narathiwatt, Thailand.

Nayan, S. (2006). Keprihatinan yang luntur terhadap warga emas. Jurnal Intelek, 4(1), 95-105.

Peprah, W. K. (2018). Predictive Relationships among the Elements of the Fraud Diamond Theory: The Perspective of Accountants, International Journal of Academic Research in Accounting, Finance and Management Sciences 8 (3): 141-148.

Piaw, C. Y. (2006). Kaedah penyelidikan. Kuala Lumpur: Mc Rraw Hill.

Royo, M. A. \& Woo, S. F. (2010). Faktor-Faktor yang mendorong tekanan kerja (stres) di kalangan guru-guru sjk(c): Satu kajian di tiga buah sekolah di Wilayah Persekutuan. Universiti Teknologi Malaysia. Unpublished article. pp, 1-12.

Salleh, S. F. \& Husin, S. N. M. (2014). Analisis amalan pemberian nafkah warga kelainan upaya: Kajian di Taman Rahmat. Journal of Business and Social Development, 2(1), 94-103.

Sharif, N., Alavi, K., Subramaniam, P. \& Zamani, Z. A. (2015). Pengalaman dan faktor pengabaian warga emas dalam komuniti. E-Bangi: Journal of Social Sciences and Humanities, 10(1), 118-134.

Tan, P. C., \& Ng, S. T. (2000). Ageing in Malaysia: Issues and policies, in Phillips, D. R. (ed.). Ageing in the Asia-Pacific region: Issues, policies and future trend. New York: Routledge, Taylor and Francis Group.

Zaidan, A. K. (2000). Al-mufassal fi ahkam al-mar'ah wa bayt al-muslim fi al-syari'ah alislamiyyah. Lubnan: Muassasah al-Risalah.

Zakaria, M. R. (2015). Kecuaian dan pengabaian kanak-kanak oleh ibu bapa: Kedudukannya di bawah akta kanak-kanak 2001 dan prinsip Syariah. Jurnal Undang-undang dan Masyarakat, 19, 37-49. 